\title{
Population Density and Solar Radiation Effect on the Residential Buildings Forms: Case Study of the Graduates Villages at EI -Burullus Lake

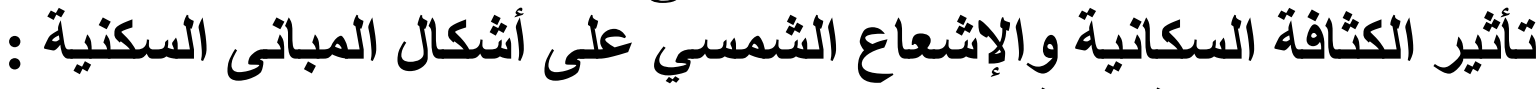 دراسة حالة قرى الخريجين على بحيرة البرلس الثبانس
}

\author{
Mokhtar H.Akl, Dr ${ }^{1}$. Sherif A. Sheta ${ }^{2}$ and Dr. Ibrahim R. Hegazy ${ }^{3}$ \\ ${ }^{1}$ Teaching Assistant, Architecture Dept, Mansoura University \\ ${ }^{2}$ Associate Professor, Architecture Dept, Mansoura University \\ ${ }^{3}$ lecturer, Architecture Dept, Mansoura University
}

\begin{abstract}
ملخص البحث
تقترح هذه الدراسة منهجية لإعادة تأهيل قرى الخريجين المصرية ببحيرة البرلس كمجاورات سكنية

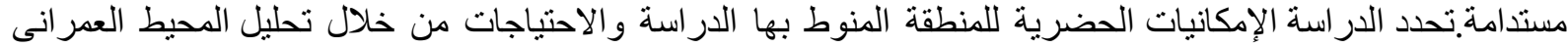

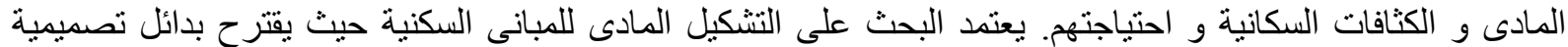

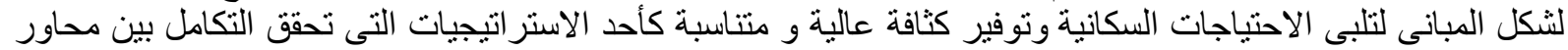

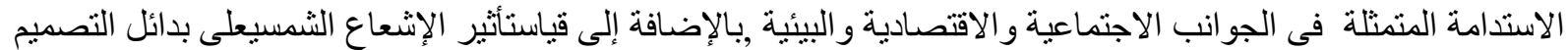

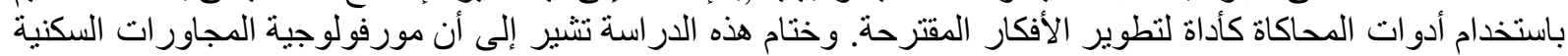

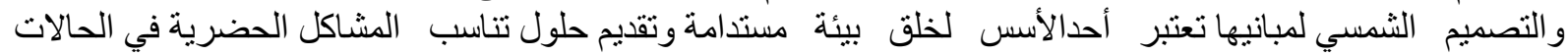

المماثلة
\end{abstract}

\begin{abstract}
This paper suggests a methodology to regenerate Egyptian Hinterlands Graduates villages at El-Burullus Lake into sustainable neighborhoods. The study defines urban potentials for the through the analysis of current physical urban context and population densities and their needs. It focuses on the optimization of physical urban form for residential buildings. The proposed methodology introduces and analyzes alternative design models for the residential building forms with respect to residents' needs, approaching high density population as a strategy to develop social, economic and environmental aspects of sustainability. The effect of solar radiation on design alternatives could be measured using simulation tools to develop design concepts.

The conclusion of this study indicates that the morphology of a sustainable neighborhood and the solar design of its residential buildings should serve as a foundation of sustainable environment and offer suitable solutions for urban problems in similar cases.
\end{abstract}

\section{Keywords}

Neighborhood Design, Urban morphology, El-Burullus lake, Solar radiations 


\section{Introduction}

Sustainable Developments should advocate the environmentally responsible model of neighborhoods and provide socially balanced population with suitable opportunities for habitats' income and diversity of use with suitable energy and mobility systems. This paper focuses on the physical forms of the residential buildings and their capacity.

\subsection{Research problem}

In Egypt, urban impact for unsustainable planning led to many problems which could be summarized in 3 main issues (1) over-population with complicated urban crises and challenges in old cities at Nile valley and Delta, (2) 95\% of Egypt lands are vacant and undeveloped and (3) the planning strategies for some new urban approaches aren't sustainable and couldn't satisfy the community needs as introduced in the case study.

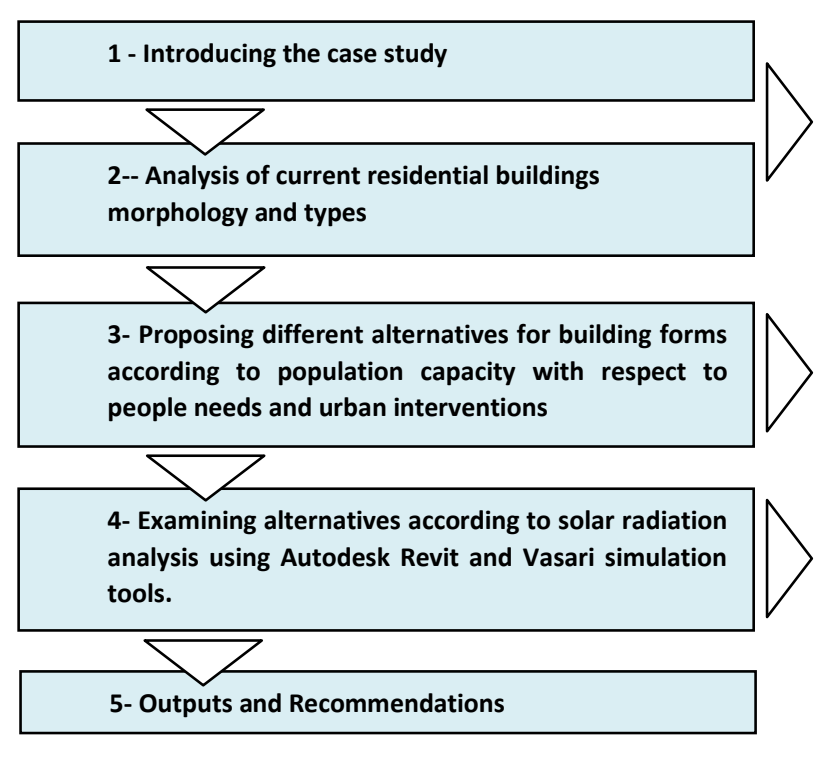

Fig. 1: The research methodology and objectives, Source: Authors

\subsection{Aims of the research}

This paper aims to propose a methodology for optimizing urban parameters that would collectivly promote high density urban growth and maximize land efficiency, optimize the use of land, and provide a variety of lot sizes and housing types to cater for the diverse housing needs of the community, at densities which can ultimately support the provision of local services with the use of solar design simulation. It aims to develope the 3 villages so that they could be regenerated into Sustainable Neighborhoods.

\subsection{Research methodology and objectives}

The research methodology and the objectives could be summarized as following:

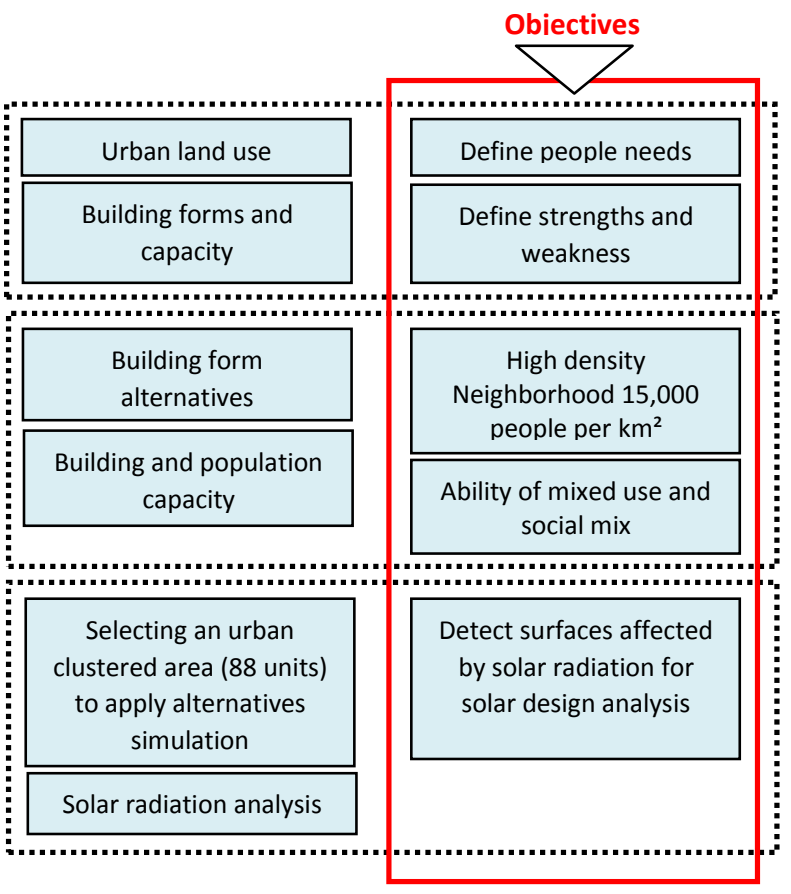

\section{Introducing the Case Study}

\subsection{Case study location}

El-Burullus Lake lies on the eastern side of Rosetta branch of the Nile River at Delta region. Delta region is characterized with very high densities in most of its Urban \& rural areas with Deteriorated infrastructure suffering from unsustainable urban impacts except for the coastal axis which has the ability for recent development.

The case study is located at Kafr el-Sheikh Governorate at Metopas center at the north 
of El-Burullus lake where the 3 villages are related to its management and polices. It connected to the international coastal road which acts as an important axis for future urban development and to an electricity link which would provide an opportunity to the feasibility of renovating sustainable neighborhoods.

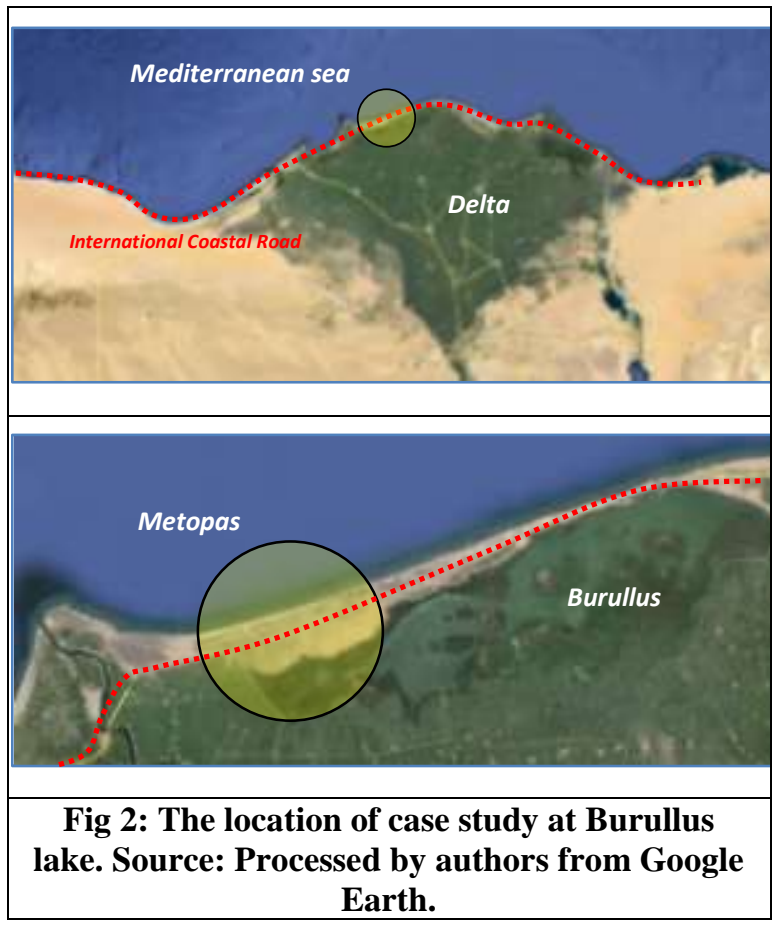

The area is divided into 3 locations named by SidiTalha, El-Said El-Badawy, and Ebrahim El-Desouky villages, Fig. 3.

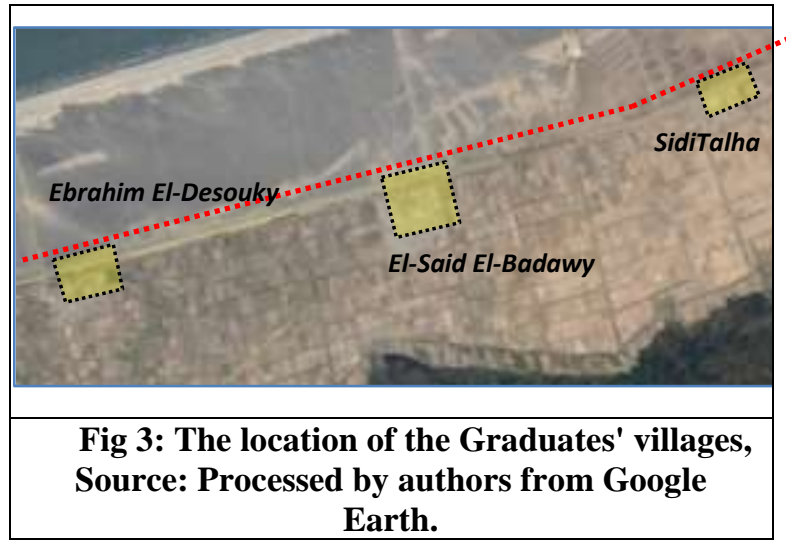

\subsection{Analysis of site potentials}

El-Burullus lake area is characterized by many resources such as agriculture, livestock farming, fish farming, reed harvesting, bird hunting, tourism and recreation but human interventions and pollution threatened its biodiversity and led to excessive use of resources(Shaltout, 2010).

El-Burullus region is divided into 3 main zones as shown in Fig.4 (1) urban development of the coastal area to be touristic and residential area and services, (2) the area of 3 villages Surrounded by their own agriculture lands which the most important resource for residents economics, each family has 2 or 4 acres from agriculture lands and (3) agriculture lands of Kafr El-Sheik governorate

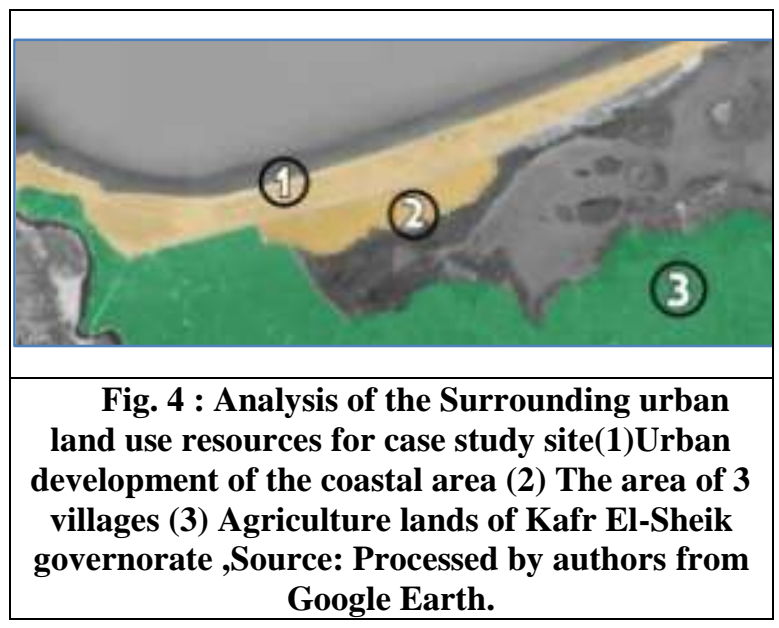

Water bodies are considered as the 2nd main resource for residents' economics which are (1) Mediterranean sea which could be an important resource for agriculture through water desalination, (2) Burullus lake: The water quality of the lake has changed over time; these changes are related to human intervention and eutrophication processes and (3) Nile river (Rosetta branch)

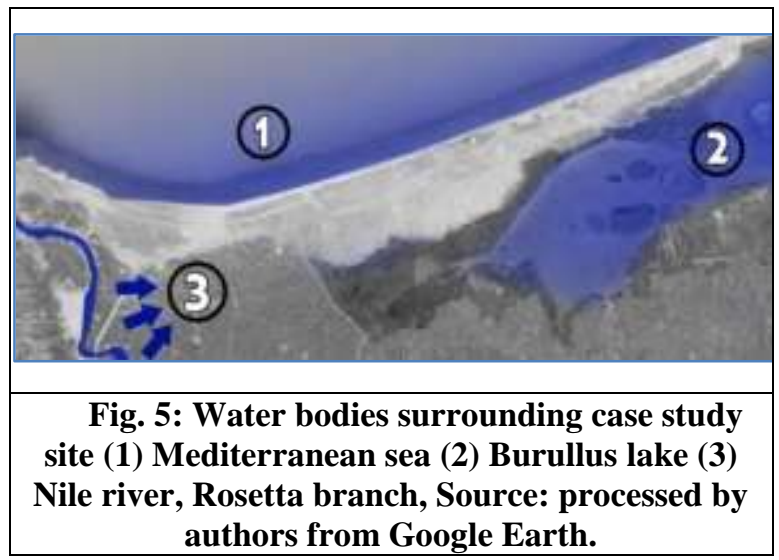


Some of the current local residents are from the surrounding rural and urban areas and most of them left their own lands vacant.

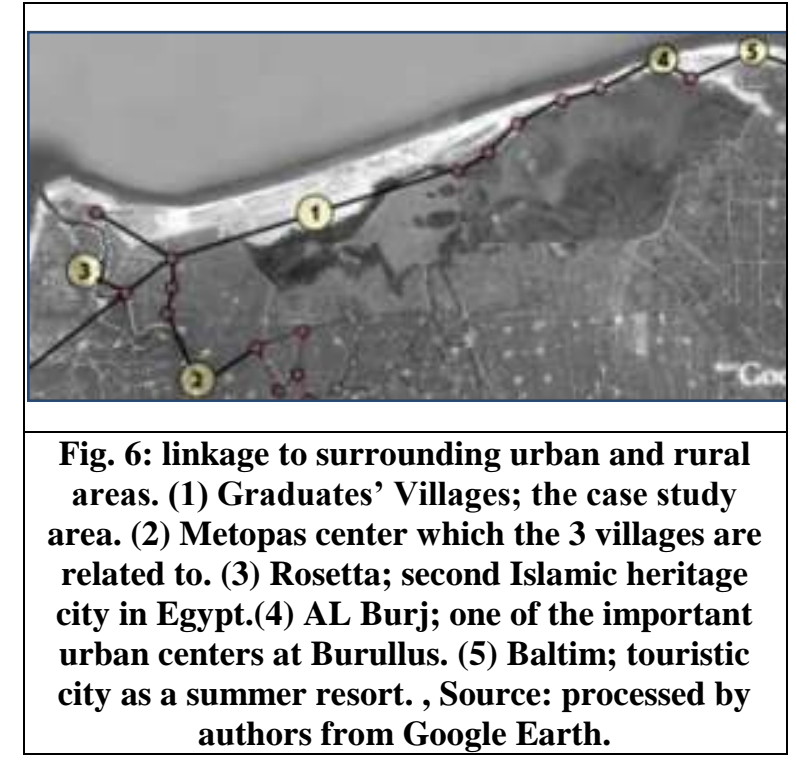

The abandonment of the residents has many reasons such as the lack of services and job opportunities at the 3 villages which are neglected without any development, the salinity of soil in some agriculture areas, no development in agriculture and irrigation techniques, the unsuitable design for the residential buildings, although the site is connected to electricity but there is no approaches for integrating sustainable energy techniques or energy conservation, no water management although the availability of surrounding water bodies, unsuitable sewage system affected by rainfall in winter finally but not least no available stations for transportation or internal mobility system.

\subsection{Analysis of 3 Graduates villages land use}

The study deals with population densities and building capacity and its morphology problems. As shown from the previous analysis, the location of the 3 Graduates villages is surrounded by the agriculture which prevent any further horizontally urban extensions so any urban extension. The following comparative land use analysis for the 3 villages defines the percentage of residential zones and its population capacity compared with the area required for services and open areas represented by internal streets and urban spaces and the population (Table 1).

The percentage of urban land use shows that 3 villages have a very low population density which doesn't exceed 4600 person in about $0.58 \mathrm{~km} 2$ in the case of El Said El-badawy village. Compared with low density, high density has economic, social and environmental benefits as it provides efficient land use, reducing public service costs, car dependency and parking demand, increasingsupport for public transport, public open space and more energy efficiency.

Services areas (educational, medical, recreational, social activities ... etc) are planned to allow people to make short walkng trips and provide other opportunities for individuals to live and work in close proximity but they are mostly empty without sufficent services so residents have to travel to other places.

Some of the residential buildings are converted to commerical uses for residents daily needs especially in El-Said ElBadawy as the distance exceeds $500 \mathrm{~m}$ to services areaat the south end of the villages.

Internal Streets are unpaved and urban spaces are vacant without any landscaping or urban design. 
Table 1: Comparative analysis of urban land use for 3 villages, Source: Authors

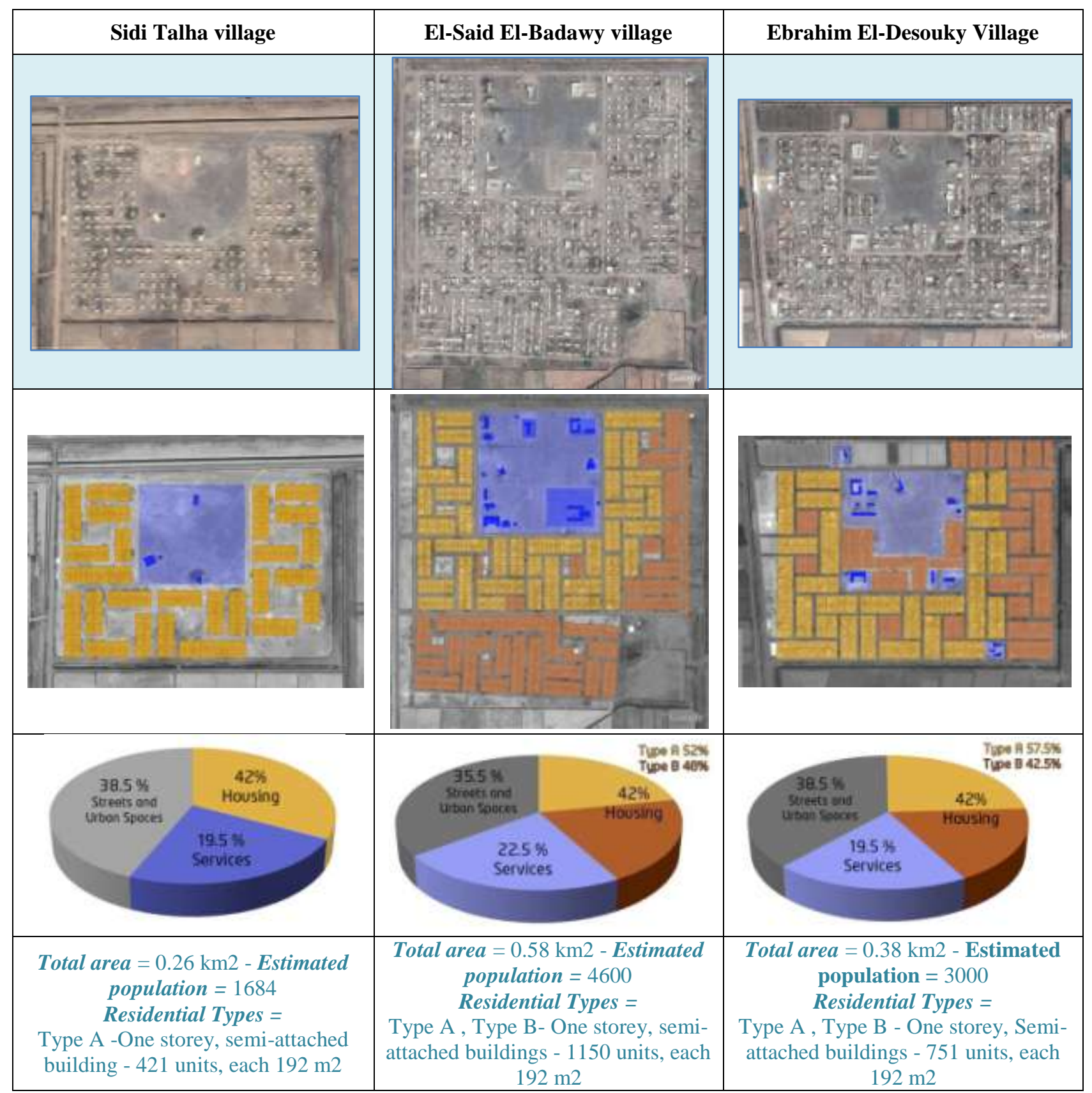

\subsection{Building Forms and Capacity (Housing Types)}

The residential buildings are classified into 2 Types ( Type A, Type B). each of them is semi-attached one storey building. The following table shows the 2 residential building types and design, built area ratio and its compatibility with residents needs. 
Table 2 :Housing Types of Graduates villages, Source: Authors.

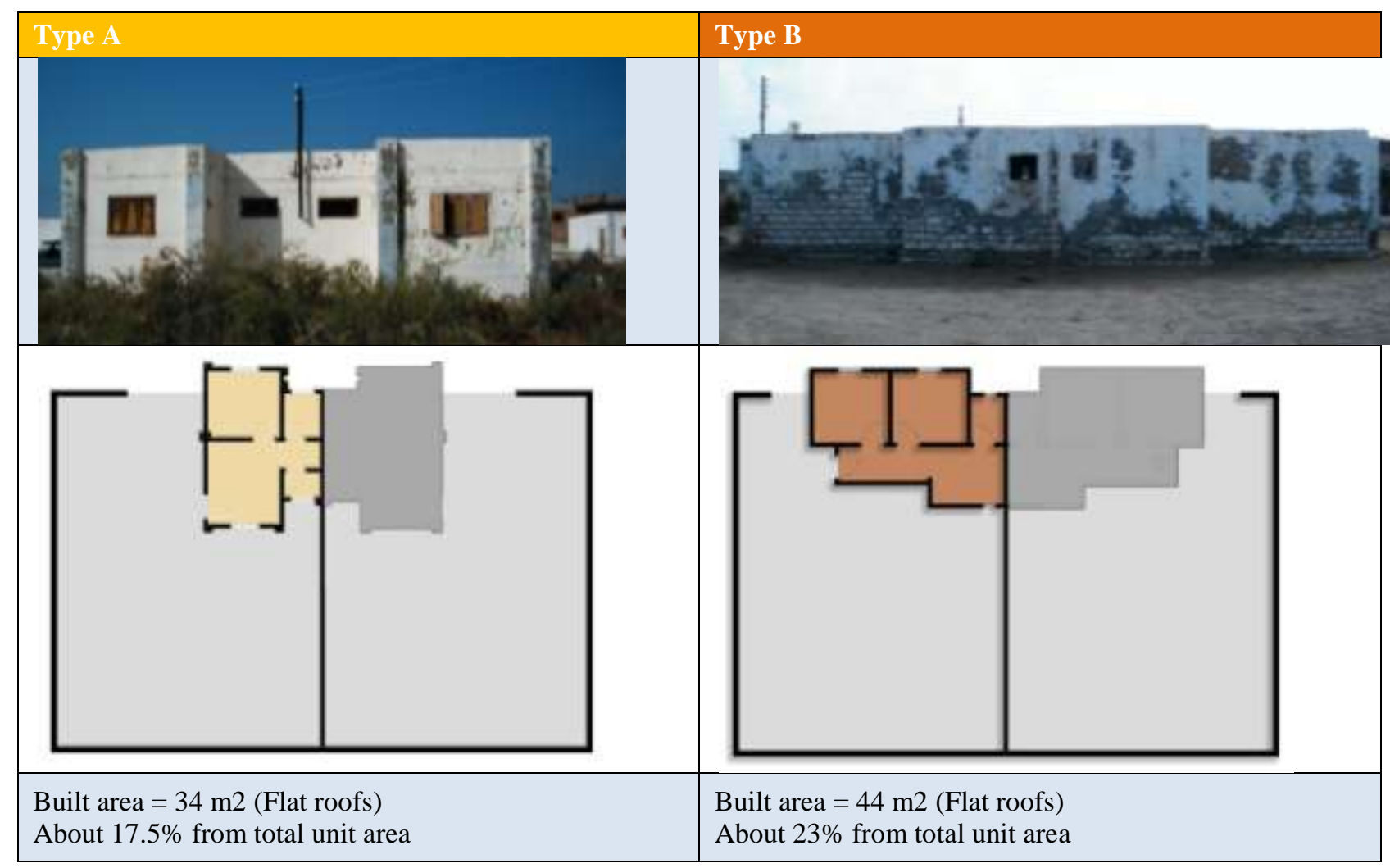

As shown from Table 2, it doesn't exceed $23 \%$ as a building footprint ratio and the rest should be used as an agriculture area for production of crops but the sandy soil which have very little clay to retain nutrients and so are not fertile and need to be replaced with productive soil to achieve the main design concept. The building units themselves with areas $34 \mathrm{~m} 2$ and $44 \mathrm{~m} 2$ at Type A and Type B repectively aren't sufficient to the residents needs as shown from people interventions, each unit should accomodate a family cosists of about 4-6 persons with the ability for vertical extension for their sons and more residents for future development.

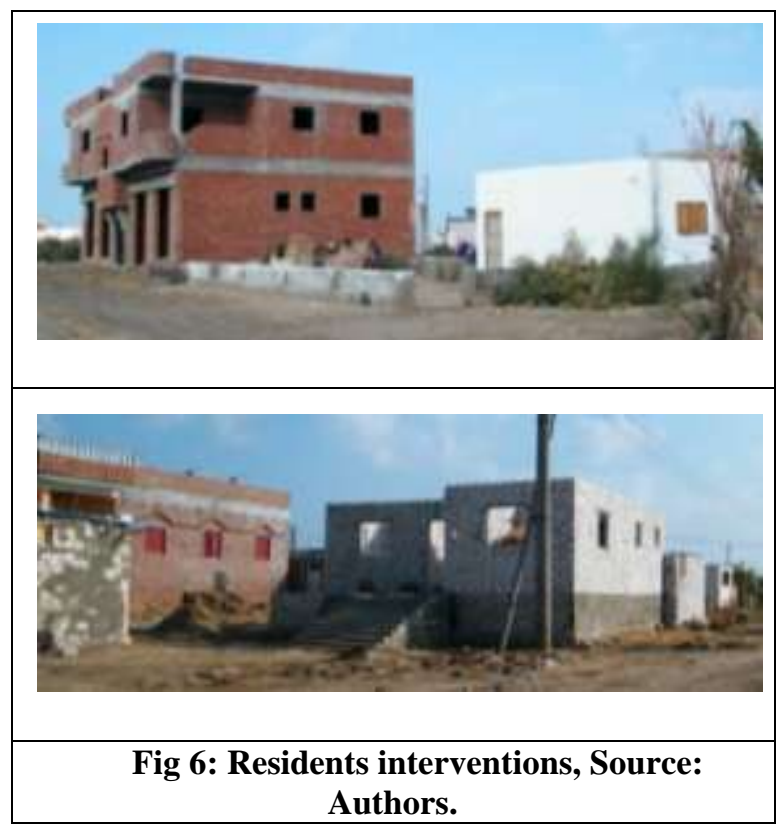

Most of residents made many modification on the building form and its design expanding its spaces to be suitable for their needs. Other interventions are done by reconstructing new buildings on the whole 
area with different structure to be further extented vertically without any regulations to control and optimize the building form or design character as shown in Fig 6.

\section{Designing and Examination of Alternatives}

The alternatives are concerned with maximizing the land value of housing areas to accommodate high densities with a minimum population 15,000 people per $\mathrm{km}^{2}$ (UN-Habitat, 2014) for each village so that it could be suitable for urban development for its services and infrastructure with a sustainable management of the surrounding resources and urban economics to be a model for a sustainable neighborhood.

Each Alternative should be represented as a family semi-attached housing with min. 2-3 storey with the ability to be extended vertically without exceeding $15 \mathrm{~m}$ height ( max. 4- 6 stories ) according to the roads width respecting the Egyptian code for residential building. The ground level could be used for commerical, dialy needs and building services.

In case of El Said El-badawy village, The population could be doubled or tripled by adjusting building form by adjusting its size area and the vertical extentions to satisfy the residents needs. An urban clustered area ( about 88 units) is selected to apply the suggeted alternatives and their simulation.

\subsection{Building forms and capacity} (Housing types)

The study suggests 3 alternatives to be discussed and evaluated. They are designed as follows:

Alternative 1: Most of people intervention demolished the current building to use the whole area as 2 or 3 storey. The alternative suggests $100 \%$ built area to be discussed and evaluated. Alternative 2: This alternative design is inspired by new cities regulation in
Egypt and their building ratio to ensure more green area and provide 3 elevations for better spatial design, solar access and ventilation.

Alternative 3: Same as alternative 2 but with smaller building ratio and smaller dwelling units but provides more urban spaces with more accessibility of wind and solar radiation.

The following table (Table 3) shows the design alternatives according to the built floor ratio and the $3 \mathrm{~d}$ forms.

As shown each form consists of 4 units which are attached in alternative 1 and semi-attached at the other 2 alternatives. The diagrams show different heights for each alternative from 1 to 4 storeys to show different building forms as the vertical extensions could be left to the owners needs or defined by specific building requirements as a planning strategy.

The Ground floor could be used for commercial needs as a mixed use strategy to provide a better access from homes to needed facilities and protect the communitywellbeing and area livability. 
Table 3: Design alternatives, Source: Authors.

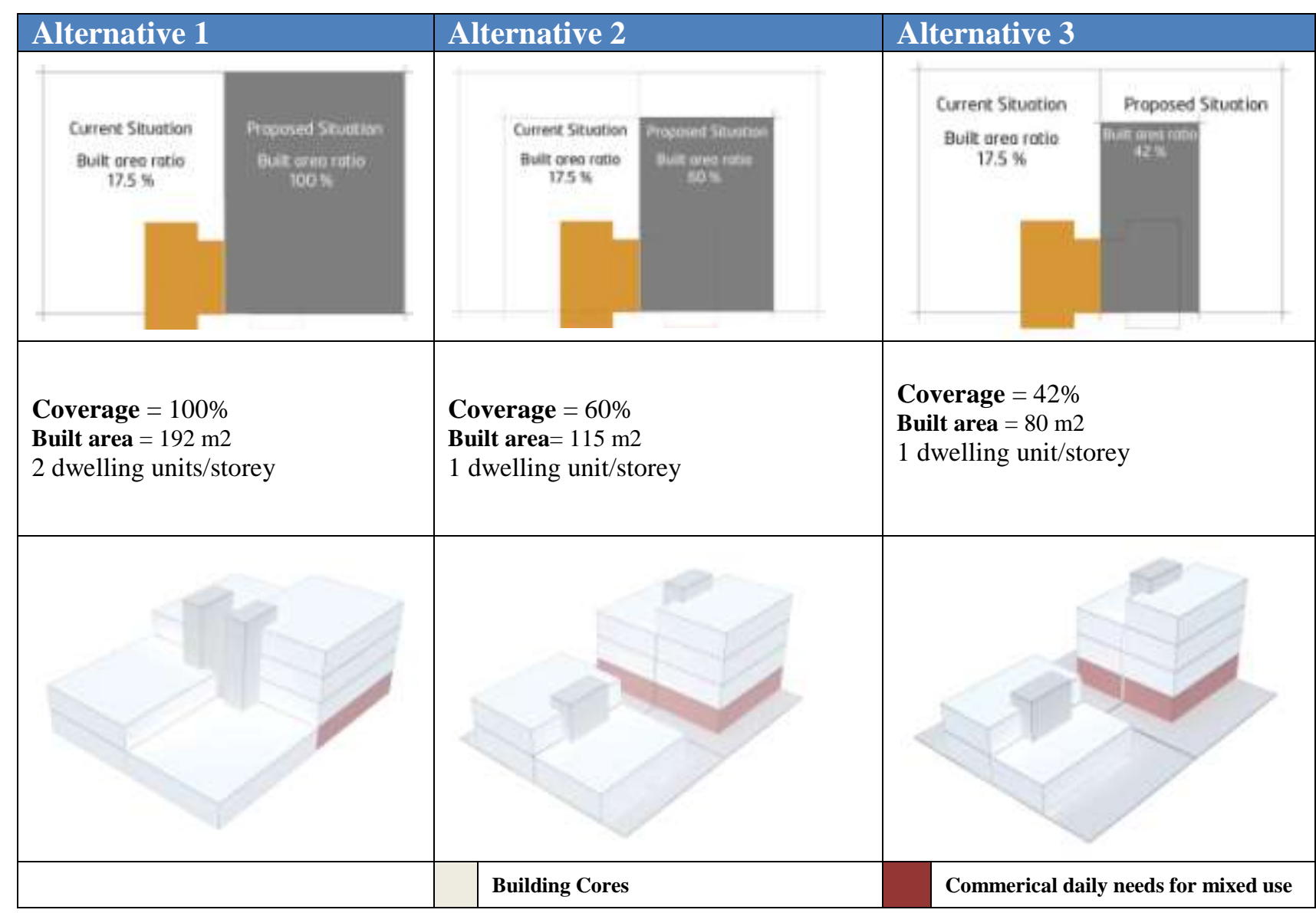

\subsection{Solar radiation analysis for proposed alternatives}

The importance of solar radiation analysis is to measure the amount of incident solar energy on building horizontal and vertical surfaces. It could be linked to energy simulation to determine load demands, predict energy generation by integrating PV systems and control solar thermal systems for domestic hot water. It is also important as a guide for material selection for building envelope as well as establishes the best orientation of building to reduce energy loads at the first design phases if it is available (Trubiano, 2013)

Revit/Vasari simulation tool is used for performing the solar radiation comparative analysis for the 3 alternatives. It is quick, easy to use and iterative test for visualizing and quantify the amount of solar radiation recevied by buildings receives whilecreatingthe conceptual mass of each alternative (Autodesk).

Solar radiation simulation analysis occuredon summer 21/06/2015 from 10 $\mathrm{AM}$ to $4 \mathrm{PM}$.Cumulative solar radiation range detected by Autodesk vasari from 0 $-4.2 \mathrm{KWh} / \mathrm{m} 2$ where the site coordinates are Longitude 30.608and Latitude 31.446. Table 4 shows the solar results on the building forms and cumulative solar radiation comparative results of the 3 alternatives. 
Table 4: Solar radiation Simulation for Design alternatives, Source: Authors using Autodesk Revit/Vasari.

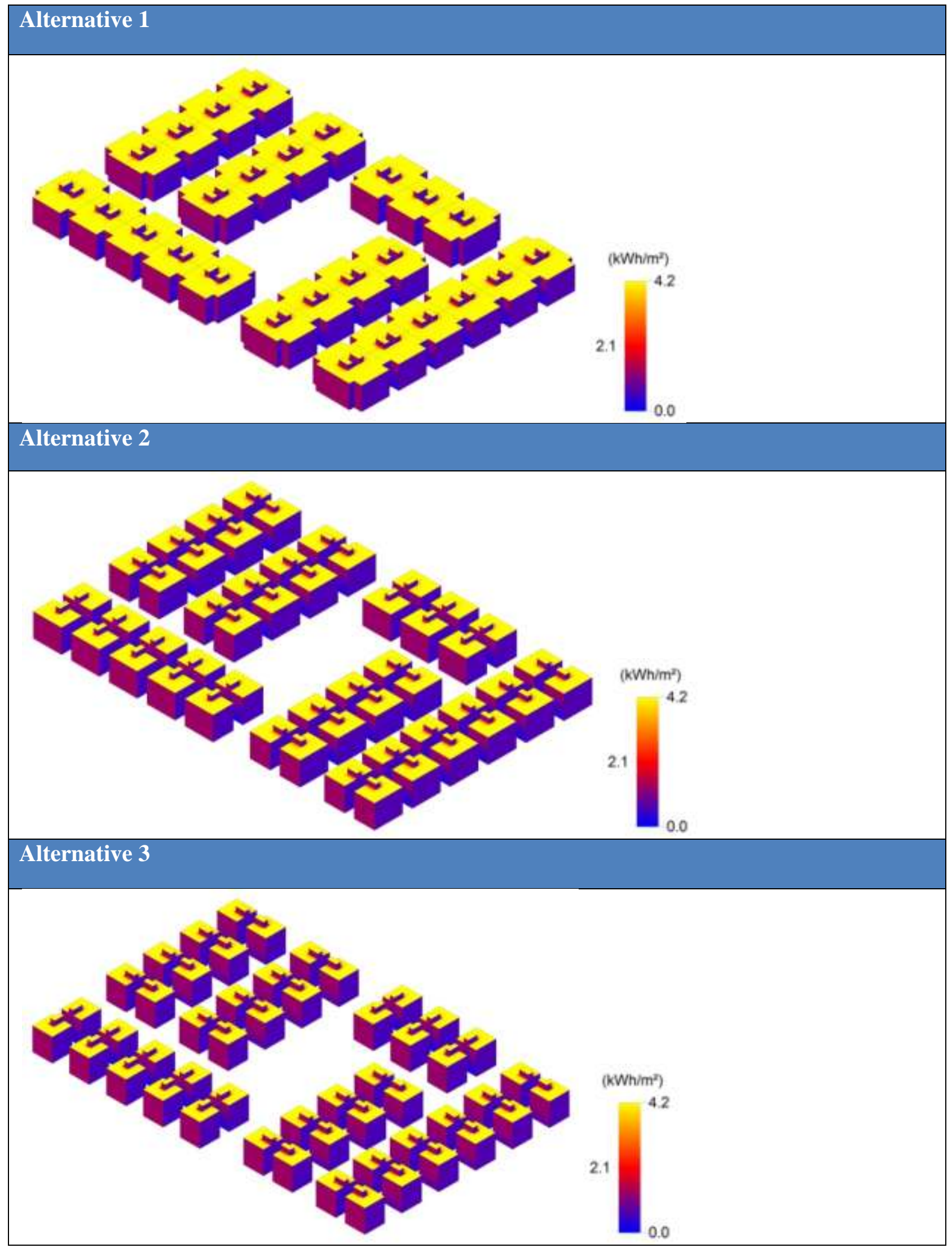


The results show that the 3 alternatives are arranged from the largest vaue to the lowest one in terms of cumulative solar radiation results as following; alternative1, alternative 2 and alternative 3 . Comparing alternative 3 with the $1^{\text {st }}$ and $2^{\text {nd }}$ alternatives results, the floor area is too small so the roofs and surfaces exposed to solar radiation will give the minimum values.

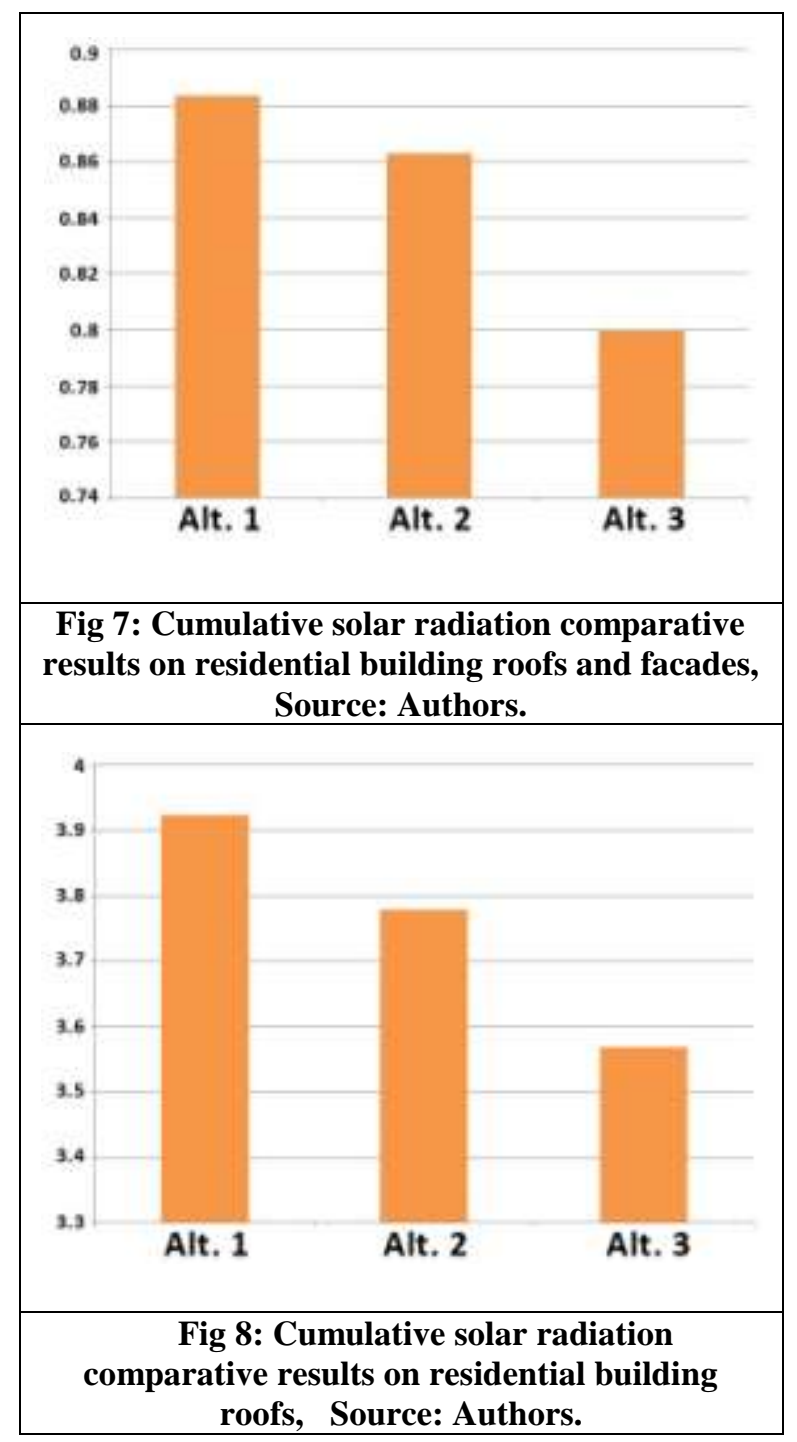

In case of alternative1, Altough it gives the best opportunity for solar design and application of PVcells as the surface floor area is the whole plot area but it offers large dwelling units which makes development of residential units expensive and difficult to market. Skylight ducts should be introduced for providing good lighting and ventilation for dwelling spaces as the units are very attached to each other with one façade.

The Study suggess that alternative 2 will be the most suitable one comparing to the others for the following reasons:

- The surface floor area is suitable for residents needs and their economic incomes.

- Each dwelling unit has 3 facades with suitable spaces between buildings to provide good daylighting and ventilation for the interior spaces.

- Solar radiation simulation shows that the difference between alternative 1 and 2 is too close and its ability to integrate sustainable solar techniques is available.

\section{Conclusion and Recommendations}

The case study results show that the current built envirnoment have many problems which led to the abandonment of its residents with the absence of development strategies to regenerate these villages into sustainable neighborhood models neglecting the potentials of the site and the surrounding environment. The development of site infrastructure, Mobility systems, services, energy and resource management must be integrated with the regeneration of building forms and its population to accommodate high density to ensure economic, social and environmental sustainabilty.

The study deals with the current urban context, landuse and buliding forms maximizing the land value of housing zones offering a suitable areas and further extensions to satisfy residents needs. The study offers a methodolgy depending on studying, discussing and analyzing different building forms comparing them using simualtion tools as aguide to environmental design approaches in the first design sketches and concepts.

The study suggests 3 alternatives. Although the results recommend one alternative according to the research 
parameters, more alternatives could be represented with more studies and details can be shared and discussed with state authorities and community stakeholders to define policies and regulations to ensure robust sustainable development strategy in the context of adapting to changes in new urbanism and smart growth principles in Egypt.

\section{References}

[1] Andrew Coluccia ,Miljana Horvata. (2012). Making Toronto solar ready: Proposing urban forms for the integration of solar strategies. Energy Procedia , 1090 - 1098.

[2] Autodesk. (n.d.). Autodesk sustainability workshop. Retrieved 1 21, 2015, from http://sustainabilityworkshop.autodes k.com/buildings/vasarirevit-solarradiation

[3] Biddulph, M. (2007). Introduction to Residential Layout. UK: Elsevier Limited.

[4] Chapman, D. (2005). Creating neighborhoods and places in the built environment. Birmingham, UK: Taylor \& Francis e-Library.

[5] Egypt, N. u. (n.d.). New urban community authority portal. Retrieved 1 20, 2015, from http://www.newcities.gov.eg/english/ New_Communities/October/default.a spx

[6] Hugh Barton, Marcus Grant and Richard Guise. (2003). Shaping neighborhoods a guide for health, sustainability and vitality. London: Spon press: Taylor and Francis group.

[7] I.R. Hegazy, W.S. Moustafa. (2013). Toward revitalization of new towns in Egypt case study:Sixth of October. International Journal of Sustainable Built Environment (2), 10-18.

[8] Javier Mozas, Aurora Fernández Per. (2006). Density: New Collective Housing. Spain: a+t architecture publishers.
[9] LEED. (2009). Green Neighborhood Developments. U.S.: U.S. Green Building Council.

[10] M. U. (2012). Combined Renewable Energy Techniques for the development of the Egyptian Hinterlands. Mansoura, Egypt: Postgraduate, Research and cultural Affairs Sector, Mansoura unversity.

[11] Minchin, C. E. (2003). Neighborhoods for living: A Guide for Residential Design In LEEDS . Leeds, UK: Leeds City Council,Development Department.

[12] Neal, P. (2003). Urban Villages and the Making of Communities. London and New York: Spon Press.

[13] Shaltout, K. H. (2010). Towards Mainstreaming Lake Burullus Biodiversity,North Egypt. Assuit University Bull. Environ. Res. Vol. 13 .

[14] Trubiano, F. (2013). Design and construction of high-performance homes; Building envelope, renewable energies and integrated practice. london and New York: Routledge, Taylor \& Francis group.

[15] UN-Habitat. (2014). Discussion note 3: A new strategy of sustainable neighbourhood planning: Five Principles. Nairobi, Kenya: UNHabitat:Urban Planning and Design Branch . 